\title{
The Power and Limitations of Influenza Virus Hemagglutinin Assays
}

\author{
N. B. Ustinov, E. G. Zavyalova*, I. G. Smirnova, and A. M. Kopylov \\ Lomonosov Moscow State University, Faculty of Chemistry, 119991 Moscow, Russia; E-mail: zlenka2006@gmail.com
}

Received May 12, 2017

Revision received August 8, 2017

\begin{abstract}
Influenza virus hemagglutinins (HAs) are surface proteins that bind to sialic acid residues at the host cell surface and ensure further virus internalization. Development of methods for the inhibition of these processes drives progress in the design of new antiviral drugs. The state of the isolated HA (i.e. combining tertiary structure and extent of oligomerization) is defined by multiple factors, like the HA source and purification method, posttranslational modifications, $\mathrm{pH}$, etc. The HA state affects HA functional activity and significantly impacts the results of numerous HA assays. In this review, we analyze the power and limitations of currently used HA assays regarding the state of HA.
\end{abstract}

DOI: $10.1134 / \mathrm{S} 0006297917110025$

Keywords: influenza virus, surface antigens, influenza hemagglutinin, inhibitors of hemagglutination, monoclonal antibodies, ELISA

Influenza is one of the most common infectious diseases: $5-10 \%$ of adults and $20-30 \%$ children are infected with influenza each year. Influenza infection itself lasts only for several days, but the high risk for human health comes from secondary infections that develop in influenza-damaged tissues and from complications that result from preexisting conditions (pregnancy, immunodeficiency) or disorders (diabetes, obesity, cardiovascular disorders). The annual number of influenza-associated deaths is 250,000 to $500,000[1,2]$.

Influenza virus belongs to the Orthomyxoviridae viral family, the most dangerous member of which is influenza A virus. Influenza virus consists of a membrane-enveloped ribonucleoprotein core. Its genome is segmented and contains eight antisense RNAs coding for 11 viral proteins. Viral surface proteins provide virion interaction with the host cell plasma membrane (hemagglutinin, HA), fusion of the virus membrane with the

Abbreviations: a.a., amino acid residue; ELISA, enzyme-linked immunosorbent assay; ER, endoplasmic reticulum; GA, Golgi apparatus; HA, hemagglutinin; HA0, hemagglutinin precursor; HA1, hemagglutinin subunit 1; HA2, hemagglutinin subunit 2; HAI, hemagglutination inhibition assay; IEP, immunoelectrophoresis; MAb, monoclonal antibody; NA, neuraminidase; RIA, radioimmunoassay; RIP, radioimmunoprecipitation; SA, sialic acid; SRID, single radial immunodiffusion.

* To whom correspondence should be addressed. endosome with subsequent nucleoprotein release from the endosome (HA and M2 protein), and detachment of the newly synthesized virus particles from the host cell surface (neuraminidase, NA) [3-5]. Surface proteins are the major targets for existing antiviral drugs: Arbidol (umifenovir) inhibits HA at the step of the virus membrane fusion with the endosome [6-8]; amantadine and rimantadine inhibit the M2 protein [9, 10]; zanamivir, oseltamivir, and peramivir inhibit NA [9-12]. Rapid microevolution of the influenza virus results in an extremely high variability of its surface proteins, which ensures rapid selection of strains resistant to the action of existing antiviral drugs. Present-day influenza virus strains are already resistant to amantadine and rimantadine [13]. For this reason, active search for new antiviral agents, including HA inhibitors, has to be continued [14, 15]. HA is the most promising target for the new drugs, because it is responsible for the very first stage of viral infection, namely, virus attachment to the host cell. Since $\mathrm{HA}$ is not an enzyme, potential HA inhibitors should either inhibit low $\mathrm{pH}$-induced conformational transitions of HA or prevent formation of the complex between HA and cell surface molecules (including oligosaccharides). The main obstacle in the design of new HA inhibitors is that they cannot be characterized by standard enzymological methods and should be tested in a carefully chosen in vitro test system. In our review, we discuss the capabilities and limitations of the currently used test systems. 
It is not surprising that influenza virus HA has been actively studied - dozens of reviews have been published that search for the correlation between the HA structure and influenza virus virulence. Because HA is a highly variable protein, data on its structure and functions have been accumulated in large dynamic databases, such as the Influenza Research Database (www.fludb.org) and GisAid (www.platform.gisaid.org). Several recent reviews summarize structural properties of HAs from different viral strains [16], effects of posttranslational modifications on the virus virulence [17], HA functional properties (especially, its $\mathrm{pH}$-dependent conformational transitions) [16, 18], and data on the mapping of viral antigenic determinants [19].

The properties of HA outside the virus are affected by multiple factors. The first is the HA primary structure and diverse posttranslational modifications. Multiple virus mutants have been characterized, and the obtained information was used to identify phylogenetic relationships between these viruses (see GisAid database and [20]). The second and the third factors are HA conformation and extent of oligomerization. If the primary structure and posttranslational modifications are determined by the virus strain and the host cell, HA conformation and extent of oligomerization (defined by us as the "HA state") depend on the method for HA isolation and some external parameters, such as $\mathrm{pH}$, buffer composition, etc.

HA forms functionally active trimers in the virus envelope [19]. Isolated HA can exist either as an active trimer or inactive oligomers composed of a varying number of HA monomers. The number of HA molecules in the oligomer depends greatly on posttranslational modifications, especially, polysaccharide attached to Asn residues in HA [17].

This existence of diverse HA states often causes ambiguities in the estimates of the activity of HA inhibitors or affinity of other HA-interacting molecules, e.g. antibodies (see section "Variety of anti-HA antibodies" of this review). Thus, $\mathrm{IC}_{50}$ values for the same inhibitor might differ ten times depending on the HA state.

In this article, we review procedures for $\mathrm{HA}$ isolation and methods for the estimation of its functional activity. Special attention is given to the HA states and test systems that could be used for the development of molecules that would recognize these states (e.g. aptamers and antibodies capable of blocking HA interaction with its ligands).

\section{STRUCTURE AND FUNCTIONS OF HEMAGGLUTININS}

Influenza virus HA is an integral membrane protein. It is synthesized as a single precursor polypeptide chain in the endoplasmic reticulum (ER) of the host cell. The precursor molecule undergoes processing that includes (i) trimerization in the ER [21], the vesicular-tubular cluster of the Golgi apparatus (GA), or the cis-Golgi network [22,
23] (depending on the virus subtype); (ii) glycosylation [24] and removal of the N-terminal signal peptide [25] in the ER; (iii) palmitoylation of the terminal $\mathrm{COOH}$-group in the early GA cisterns [26]; and (iv) cleavage in the trans-Golgi network with the formation of two polypeptide chains connected by a disulfide bond [27, 28]. HAs of the highly pathogenic avian influenza virus $\mathrm{H} 5$ and $\mathrm{H} 7$ subtypes are cleaved by cellular subtilisin-like proteases [29]. In other virus subtypes HAs are cleaved predominantly by the transmembrane type II serine proteases [30].

The HA molecule in the virus membrane consists of the hydrophilic ectodomain exposed at the membrane outer side, one small transmembrane domain (24-28 a.a.), and one cytoplasmic domain (10-55 a.a.) [31]. Crystal structures for the ectodomains of mature HA [32, 33] (Fig. 1b) and its precursor (HA0) (Fig. 1a) [34] have been solved. The ectodomain consists of distal globular and proximal fibrillar fragments corresponding to HA subunits 1 and 2 (HA1 and HA2), respectively. The surface of the globular fragment bears HA antigenic determinants [35] and serves as a binding site for sialic acids (SAs) of the host cell surface [36]. The fibrillar fragment is formed by six $\alpha-$ helices (two helices from each HA2 molecule); three of them are wound in a left-handed superhelix.

In addition to the supercoiling of the ectodomain fibrillar fragment, HA quaternary structure (Fig. 2) is stabilized by noncovalent interactions between monomer subunits. It was found that stability of the HA trimer in the pandemic $\mathrm{A}(\mathrm{H} 1 \mathrm{~N} 1) \mathrm{pdm} 09$ strain is determined by amino acids at positions 205 and 402 in the HA1 and HA2 subunits, respectively (Fig. 2) [37]. Another driving force for trimerization is the orientation effect of the membraneanchored C-terminal sequence of HA2. Thus, both fullsize HA [38] and HA with the C-terminal glycosylphosphatidylinositol anchor in place of the transmembrane and cytoplasmic domains [39] form trimers, whereas isolated ectodomain is incapable of spontaneous trimerization [38]. Disulfide bonds between the subunits are another important factor that, together with protein-lipid interactions, affects the structural stability and functional activity of HA molecules. Formation of disulfide bridges between cysteine residues of the transmembrane and cytoplasmic domains is critical for protein trimerization [40]. Interestingly, isolated HA1 molecules, but not ectodomains, can form biologically active trimers [41]. Trimerization in the absence of transmembrane domains is initiated by the interactions between the Ile3-Cys4-Ile5 amino acid triads [42].

The structure and functional activity of HA trimers depend on the conformation of monomeric subunits. It was found that about $10 \%$ of HA precursor molecules in vivo are not cleaved by proteases and form aberrant inactive trimers and oligomers of unknown structure that include many HA monomers [43].

The first stage of the virus life cycle is its internalization, which is accompanied by a series of conformational changes in the HA molecules. After HA1 binding to SAs 
of the host cell membrane proteins, the virus enters the cell by endocytosis. The $\mathrm{pH}$ in the endosome decreases to 5.0-5.5 due to the proton channel formation by the M2 protein. Protonation of HA2 results in disruption of noncovalent interactions in the HA globular fragment, formation of a long supercoiled region from the short and long HA2 $\alpha$-helices, and conversion of the B-loop into a new $\alpha$-helix (Fig. 1e) $[32,44]$. Because of these conformational rearrangements, hydrophobic $\mathrm{N}$-terminal fragments (a.a. 331-353) of HA2 molecules are exposed and incorporated into the endosomal membrane. The $\mathrm{N}$ - and C-termini of the HA2 polypeptide approach each other [45], which results in the fusion of the viral and endosomal membranes and release of the viral nucleoprotein into the host cell cytoplasm [5, 46, 47]. Conformational transitions of the HA molecule can be also induced by temperature shock, thereby confirming the hypothesis of a metastable state of the initial structure [48].

The surface of the HA ectodomain contains multiple sites for $\mathrm{N}$-glycosylation at asparagine residues
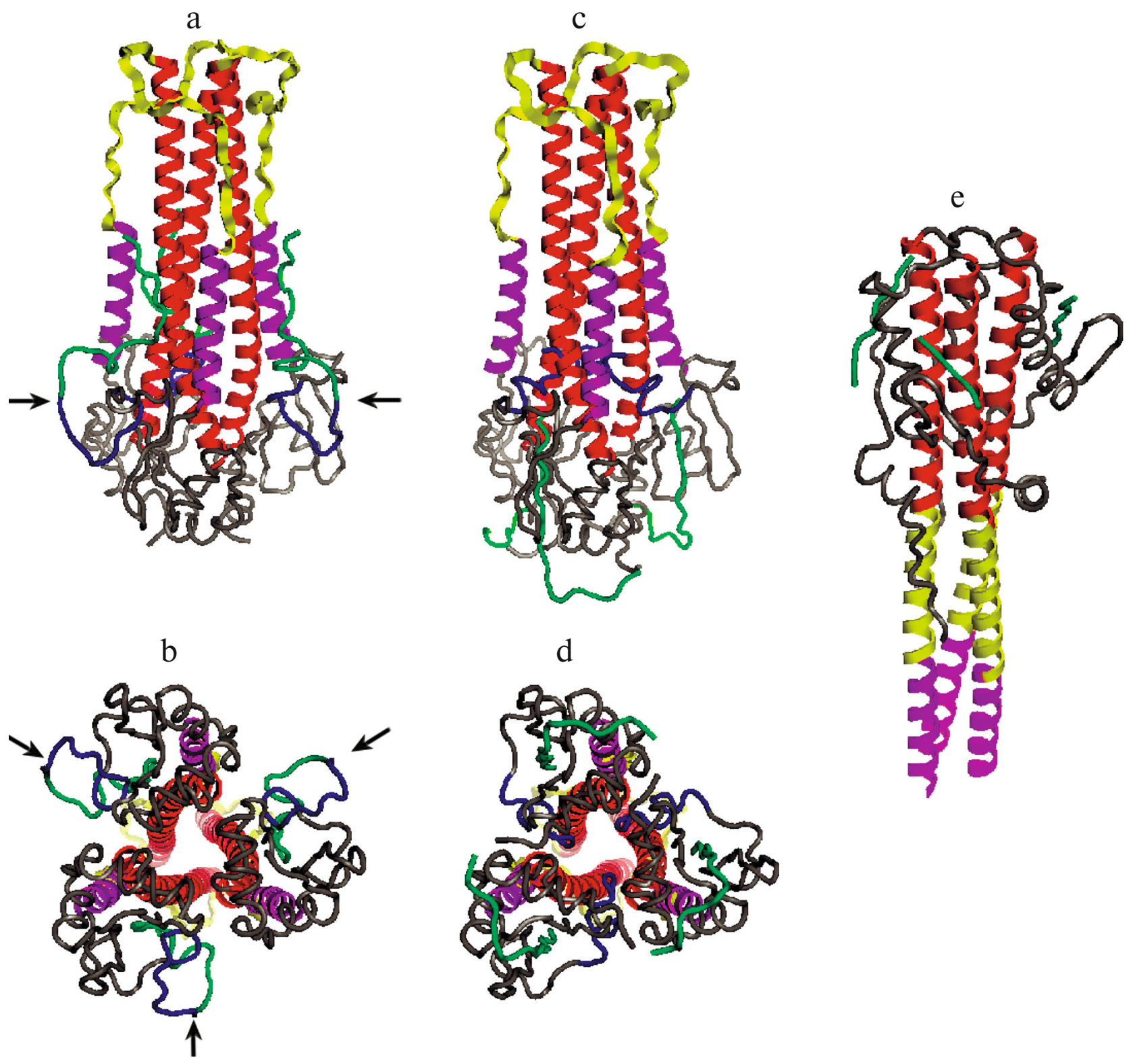

Fig. 1. Conformational changes in the HA ectodomain: a) uncleaved precursor (fragment); b) same as (a), view from the viral membrane side; c) processed HA with local conformational changes (fragment); d) same as (c), view from the viral membrane side; e) HA in the low-pH conformation (fragment). Cleavage sites are indicated with arrows. In the HA2 fibrillar fragment: red, $\alpha$-helices that form the superhelix; purple, short $\alpha$-helices; yellow, B-loops that form $\alpha$-helices during $\mathrm{pH}$-dependent conformational transition; blue and green, HA2 N-terminal (a.a. 331-342) and HA1 C-terminal fragments, respectively, released by proteolysis; gray, rest of the HA2 molecule. HA1 globular fragment and glycosylation sites are not shown. 
a

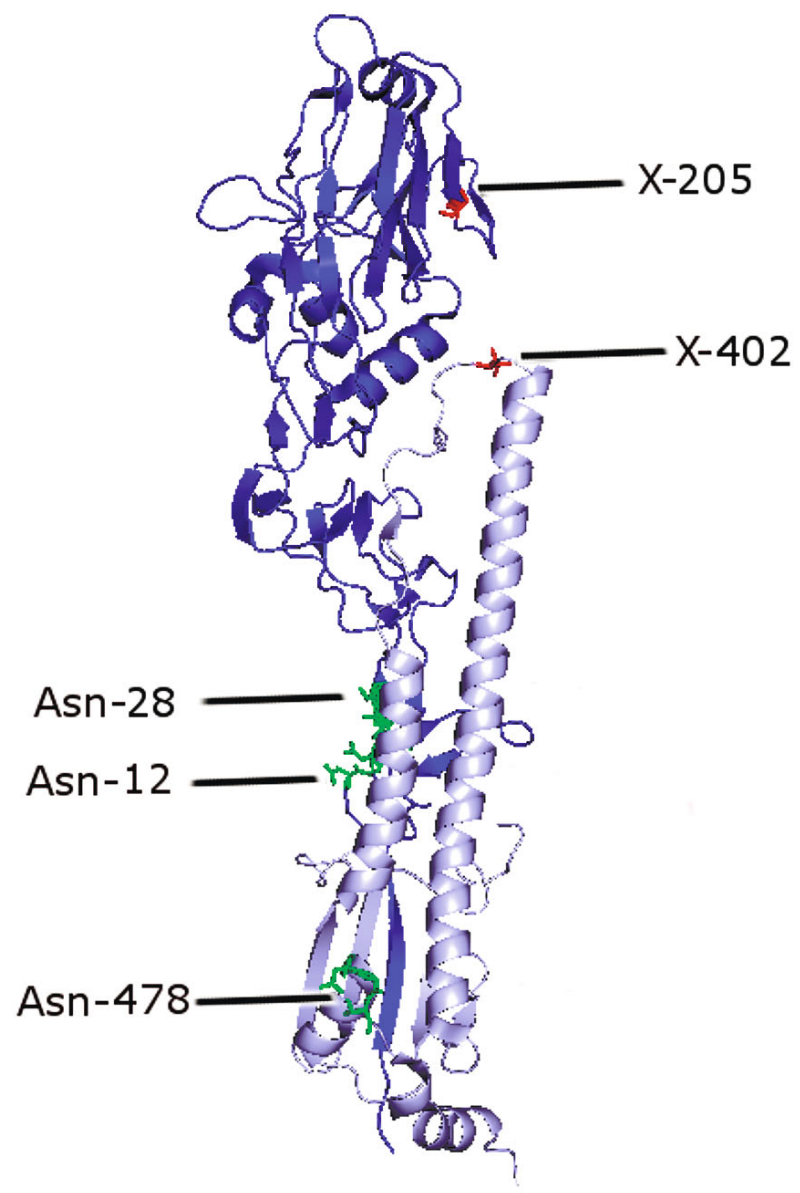

b

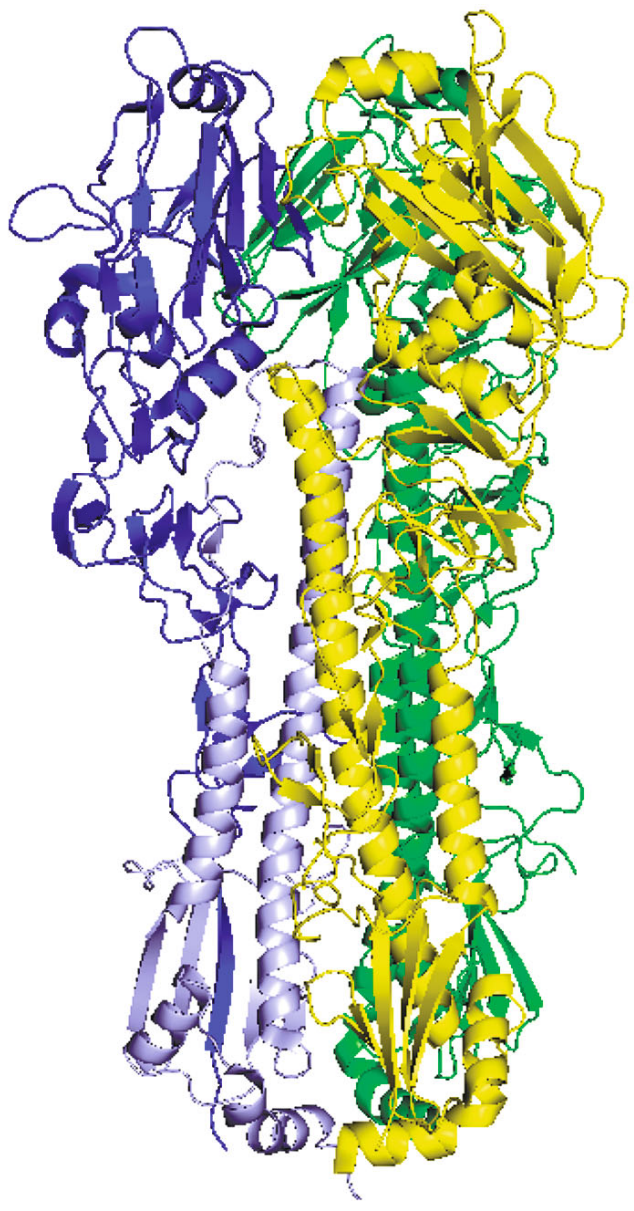

Fig. 2. a) Influenza virus HA monomer (blue, HA1; light blue, HA2). Residues 205 and 402 that determine monomer predisposition for trimerization are shown in red; conserved glycosylation sites (Asn-X-Thr), where the Asn residues are Asn12, Asn28, and Asn478, are shown in green. b) Influenza virus HA trimer (individual monomers are colored differently).

(Asn-X-Thr/Ser, where $\mathrm{X}$ is any amino acid except Pro) [49]. Two of these residues (Asn12 for HA1 and Asn478 for $\mathrm{HA} 2$; numeration as in the $\mathrm{H} 7$ subtype $\mathrm{HA} 2$ ) are strictly conserved in all known subtypes, and Asn 28 is conserved in all subtypes except $\mathrm{H} 4, \mathrm{H} 8, \mathrm{H} 9$, and $\mathrm{H} 12$ (Fig. 2) [50]. The number and chemical nature of modifying carbohydrate moieties depend on the host cells [51]. Carbohydrate moieties play an important role in HA processing and intracellular transport [24]; they also screen viral antigenic determinants at the cell surface, which suppresses immune response to the viral infection [17].

\section{ISOLATION OF HAs}

Each viral particle contains 400 to $1000 \mathrm{HA}$ molecules at its surface [51, 52]. This number is sufficient for direct isolation of HA from virions, and corresponding methods were developed in 1950s-1970s. To isolate HA, virus membranes are disintegrated with organic solvents or mild ionic detergents [53-55]. The major drawback of these procedures is that they often result in partial denaturation and aggregation of the HA; on the other hand, they preserve the glycosylation profile of the HA molecules [55].

Recombinant HA is now commercially available. However, the use of prokaryotic expression systems is hindered by (i) the need for separate expression of HA1 and HA2 subunits, (ii) the need for HA refolding after its purification from inclusion bodies [56], (iii) decreased expression levels because of partial degradation of hydrophobic regions, such as the signal peptide, HA2 Nterminal fragment, and transmembrane domain [57], and (iv) the absence of posttranslational modifications, above all, glycosylation. The latter problem could be solved by expressing HA in transgenic $E$. coli cells containing the system for protein $\mathrm{N}$-glycosylation from Campylobacter jejuni [58].

The HA expressed in eukaryotic expression systems is more suitable for functional activity studies. Recombi- 
nant HA is most commonly produced in cultured insect cells [59-61]. HAs expressed in a baculoviral expression system (i) are glycosylated and (ii) exist as trimers and/or their associates, as directly demonstrated by hemagglutination tests (see section "Purifications of HAs" of this review) or indirectly proven in exclusion chromatography studies. Thus, recombinant HA from the influenza A/New Caledonia/20/99 virus was found to be glycosylated at all six sites predicted based on the analysis of its amino acid sequence [59].

The major differences between insect cells and typical influenza virus host cells are the low activity of terminal glycosyl transferases [62], high activity of $N$-acetyl- $\beta$ glucosaminidases [63, 64], and the absence of terminal sialylation of $\mathrm{N}$-glycans [65] in insect cells. As a result, HAs, obtained in baculoviral expression systems, have different composition of modifying carbohydrate moieties and contain $N$-glycans that are shorter and less branched that in the native virus. HA with more native glycosylation profile could be synthesized using baculoviral expression vectors [66-68] or insect cell lines [69, 70] that bear genes for glycosyl transferases and proteins involved in SA synthesis and transport under control of a strong promoter [71]. So far, carbohydrate modifications typical for mammalian hosts could be reproduced in baculoviral expression systems only partially.

HAs could be synthesized directly in mammalian cells as individual proteins [72] or components of viruslike particles containing a full [73] or reduced $[74,75]$ set of recombinant viral proteins. It is preferable to use cell cultures that resemble most the natural host cells, because this would preserve posttranslational modifications and the glycosylation profile of the native virus and ensure cleavage of the HA0 precursor [61].

Therefore, the method for HA isolation determines the chemical structure of HA protein (including posttranslational modifications) and its state.

\section{HEMAGGLUTINATION TEST}

Influenza virions can agglutinate erythrocytes with the formation of a viscous gel. The agglutination occurs through the binding of virion-embedded HA to sialylated surface proteins of several erythrocytes at once.

The number of agglutinated erythrocytes is proportional to the HA content and could be used for estimating the functional activity of the protein itself and of inhibitors of complex formation between HA and SA. The classical procedure uses $0.5-1.0 \%$ suspension of erythrocytes mixed and incubated with the virus suspension, with negative control containing erythrocytes only, and positive control containing erythrocytes and virions [76]. The virus titer is determined using serial dilution of virion suspension; the functional activity of the SA-HA complex formation inhibitors is estimated by adding different inhibitor concentrations to the reaction mixture. The apparent inhibition constant $\left(K_{i}^{H I}\right)$ is defined as the lowest inhibitor concentration at which no erythrocyte agglutination is observed [77]. For polyvalent HA inhibitors (e.g. SAmodified synthetic polymers), $K_{i}^{H I}$ is calculated based on the total concentration of binding sites [78-80].

Hemagglutination inhibition assay (HAI) has been successfully used for estimating inhibition constants for SA synthetic analogs [81, 82], polyvalent SA synthetic analogs [78-80], liposomes with surface-exposed SA residues $[83,84]$, and some SA-binding proteins, e.g. $\alpha_{2}-$ macroglobulin [85]. The obtained values correlated well with the dissociation constants of the corresponding complexes determined by ${ }^{1} \mathrm{H}$ NMR analysis [77] and data of enzyme immunoassay (ELISA) [79].

The hemagglutination test can be performed not only for influenza virions, but for isolated HA molecules as well if these molecules are in the form of trimers to provide the formation of a multiple-contact network. Thus, the HA ectodomain that exists in solely monomeric form does not agglutinate erythrocytes, while oligomerization-prone HA1 (a.a. 1-330) does [86]. Removal of the HA1 N-terminal fragment (a.a. 1-8) that contains the oligomerization signal Ile-Cys-Ile results in complete loss of the HA1 activity, while removal of the C-terminal portion (a.a. 321-330), on the contrary, stabilizes the trimer and facilitates hemagglutination. The larger HA1 fragment (a.a. 1-104) is also capable of oligomerization but does not agglutinate erythrocytes because of the absence of the SA-binding site (Table 1) [42].

Table 1. Correlation between HAl oligomerization state and activity in the hemagglutination test

\begin{tabular}{|c|c|c|c|c|c|c|}
\hline HA fragment & Subtype & SA-binding site & $\begin{array}{l}\text { Expression } \\
\text { system }\end{array}$ & Composition & $\begin{array}{c}\text { Relative activity, } \\
\%\end{array}$ & Source \\
\hline $1-330^{*}$ & H5 & + & E. coli & monomer/oligomer & 100 & [42] \\
\hline $1-320^{*}$ & H5 & + & E. coli & monomer/oligomer & 4 & [42] \\
\hline $1-104^{*}$ & H5 & - & E. coli & monomer/oligomer & 0 & [42] \\
\hline $9-330^{*}$ & H5 & + & E. coli & monomer & 0 & [42] \\
\hline $1-480$ & $\mathrm{H} 1$ & + & E. coli & monomer & 0 & [86] \\
\hline
\end{tabular}

* In HA1. 
Nonglycosylated recombinant HA is active in the hemagglutination test; therefore, neither location nor the presence of glycoside moieties in the HA molecule affect its ability to bind SA and agglutinate erythrocytes.

The species specificity of HAs should be taken into consideration when performing the hemagglutination test, because mutations in HA might affect the specificity of SA binding. Thus, HAs of influenza subtypes H1, H2, and $\mathrm{H} 3$ interact with the Sia2-6Gal fragment typical for human and swine epithelial cells; HAs of influenza subtypes $\mathrm{H} 5$ and $\mathrm{H} 7$ bind the Sia2-3Gal fragment found in equine and avian epithelial cells [4, 87]. Therefore, erythrocytes of a particular biological species should be used in tests with specific virus strains. The difference in the constants of HA binding to different SA fragments is often only within an order of magnitude [88], which allows ignoring the species specificity, although the sensitivity of the method is decreased.

\section{IMMUNOCHEMICAL TESTS}

Variety of anti-HA antibodies. Antigenic determinants differ in influenza virus strains. For example, the variety of surface epitopes (as well as corresponding antibodies) could be seen in influenza virus subtype H3. The HA1 globular fragment in this virus contains four antigenic determinants (Fig. 3, a-d), as determined using an array of monoclonal antibodies (MAbs) [35, 89]. Two of the epitopes (B and especially D) are present only in the trimer, thereby making it possible to use antibodies against these epitopes for studying HA quaternary structure, e.g. by following the dynamics of HA posttranslational trimerization in vivo $[43,90]$. The affinities of the anti-D epitope antibodies differ more than ten times depending on the state of HA oligomerization [91, 92].

Structure and localization of the HA antigenic determinants in virus subtype $\mathrm{H} 1$ differ from those in subtype $\mathrm{H} 3$. Thus, HAs from subtype $\mathrm{H} 1$ have at their surface two specific ( $\mathrm{Sa}$ and $\mathrm{Sb})$ and three cross-reactive $\left(\mathrm{Ca}_{1}, \mathrm{Ca}_{2}\right.$, and $\mathrm{Cb}$ ) epitopes that are present in different strains [93, 94]. All these epitopes, except $\mathrm{Sb}$, exist only in HA trimers [95].

Antigenic determinants in virus subtypes $\mathrm{H} 1$ and $\mathrm{H} 3$ partially overlap: the B site corresponds to the Sa site and a small fragment of the $\mathrm{Sb}$ site; the D site corresponds to the $\mathrm{Ca}_{1}$ site. At the same time, the A site has a considerably smaller surface area than the $\mathrm{Ca}_{2}$ site located in the

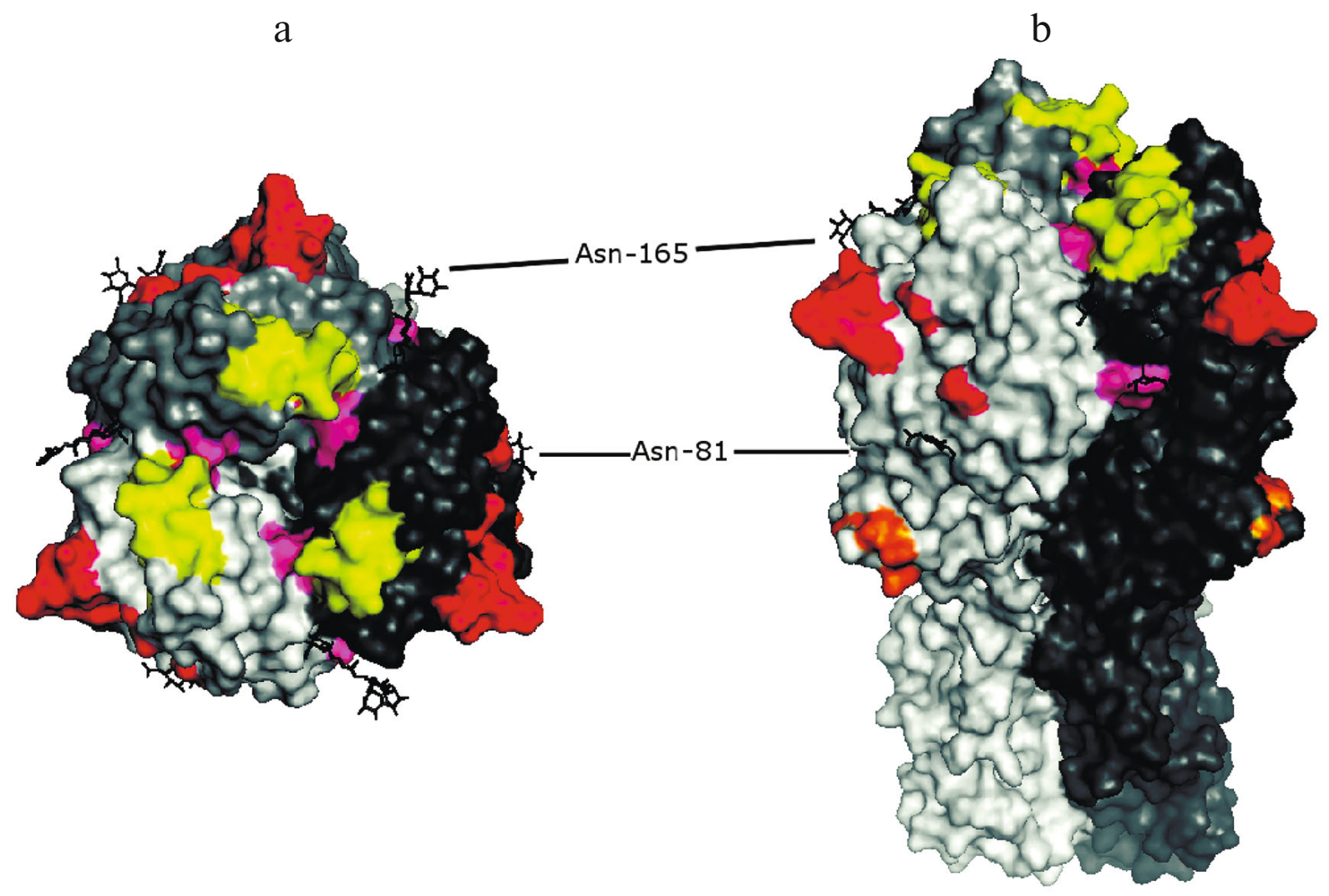

Fig. 3. Antigenic structure of the HA ectodomain from the influenza virus H3 subtype (A/Hong Kong) at pH 7.0: a) top view; b) side view. Monomers in the trimer are shown in variations of gray color; carbohydrate modification are outlined in black. HA1 epitopes A, B, C, and D are colored red, yellow, orange, and pink, respectively. Only glycosylation at Asn81 and Asn165 is shown, which masks the regions corresponding to the $\mathrm{Ca}$ and $\mathrm{Sa}$ epitopes, respectively, in subtype $\mathrm{H} 1$ strains. 
Table 2. Anti-HA antibodies and their specificity against different HA states

\begin{tabular}{c|c|c|c|c|c}
\hline \multirow{2}{*}{ Antibody } & \multirow{2}{*}{ Subunit (epitope) } & \multicolumn{2}{|c|}{ Affinity ratio } & \multirow{2}{*}{ Method } & \multirow{2}{*}{ Source } \\
\cline { 3 - 5 } & & trimer/monomer & $\mathrm{pH} \mathrm{7.0/pH} \mathrm{5.0}$ & & 5 \\
\hline 1 & 2 & 3 & 4 & 6 \\
\hline
\end{tabular}

Monoclonal antibodies against HA subtype H3

\begin{tabular}{|c|c|c|c|c|c|}
\hline N1 & $1(\mathrm{~B})$ & $\begin{array}{c}29.0^{\mathrm{a}} \\
\infty^{\mathrm{b}, \mathrm{c}}\end{array}$ & $\begin{array}{l}29.0^{\mathrm{a}} \\
15.4\end{array}$ & RIP & $\begin{array}{l}{[39]} \\
{[43]}\end{array}$ \\
\hline $\mathrm{N} 2$ & $1(\mathrm{~B})$ & $\begin{array}{l}\infty^{\mathrm{a}, \mathrm{b}} \\
\infty^{\mathrm{b}, \mathrm{c}}\end{array}$ & $\begin{array}{l}\infty^{\mathrm{a}, \mathrm{b}} \\
19.8\end{array}$ & RIP & $\begin{array}{l}{[39]} \\
{[43]}\end{array}$ \\
\hline $12 / 1$ & $1(\mathrm{~B} / \mathrm{D})$ & $\infty^{b, c}$ & 34 & RIP & {$[43,97]$} \\
\hline $\mathrm{A} 1$ & $2(?)$ & $0.15^{\mathrm{c}}$ & $4.8 \cdot 10^{-3}$ & RIP & [43] \\
\hline A2 & $1(?)$ & $0.17^{\mathrm{c}}$ & $1.5 \cdot 10^{-3}$ & RIP & [43] \\
\hline $88 / 2$ & $1(?)$ & $\begin{array}{c}6.9 \cdot 10^{-3^{c}} \\
- \\
-\end{array}$ & $\begin{array}{c}2.2 \cdot 10^{-2} \\
7.3 \cdot 10^{-2} \\
<1.8 \cdot 10^{-3}\end{array}$ & $\begin{array}{l}\text { RIP } \\
\text { RIA } \\
\text { HAI }\end{array}$ & $\begin{array}{c}{[43,97]} \\
{[101]} \\
{[101]}\end{array}$ \\
\hline A2 & $1(\mathrm{C})$ & $\begin{array}{l}- \\
1.3 \\
1.6\end{array}$ & $\begin{array}{l}1.3 \\
1.3 \\
- \\
-\end{array}$ & $\begin{array}{l}\text { HAI } \\
\text { RIA } \\
\text { RIA } \\
\text { RIA }\end{array}$ & $\begin{array}{c}{[97]} \\
{[101]} \\
{[91]} \\
{[92]}\end{array}$ \\
\hline $\mathrm{A} 20$ & $1(\mathrm{~A})$ & $\begin{array}{l}- \\
- \\
- \\
3.3 \\
2.4\end{array}$ & $\begin{array}{c}1 \\
1.3 \\
1.1 \\
- \\
-\end{array}$ & $\begin{array}{l}\text { HAI } \\
\text { HAI } \\
\text { RIA } \\
\text { RIA } \\
\text { RIA }\end{array}$ & $\begin{array}{c}{[97]} \\
{[101]} \\
{[101]} \\
{[91]} \\
{[92]}\end{array}$ \\
\hline A21 & 1 (D) & $\begin{array}{l}- \\
- \\
- \\
9.3 \\
5.9\end{array}$ & $\begin{array}{c}>1.0 \cdot 10^{3} \\
7.3 \cdot 10^{3} \\
11 \\
- \\
-\end{array}$ & $\begin{array}{l}\text { HAI } \\
\text { HAI } \\
\text { RIA } \\
\text { RIA } \\
\text { RIA }\end{array}$ & $\begin{array}{c}{[97]} \\
{[101]} \\
{[101]} \\
{[91]} \\
{[92]}\end{array}$ \\
\hline BB8 & 2 (353-368; site I) & $\begin{array}{l}- \\
-\end{array}$ & $\begin{array}{l}1.0^{c} \\
0.3\end{array}$ & RIA & [103] \\
\hline CF2 & $2(331-365 ;$ site I) & $\begin{array}{l}- \\
-\end{array}$ & $\begin{array}{l}0.6^{\mathrm{c}} \\
0.4\end{array}$ & RIA & [103] \\
\hline IIF4 & 2 (455-505; site II) & $\begin{array}{l}- \\
-\end{array}$ & $\begin{array}{l}1.0^{c} \\
0.5\end{array}$ & RIA & [103] \\
\hline CB8 & $2(368-442 ;$ site III) & $\begin{array}{l}- \\
-\end{array}$ & $\begin{array}{l}0.5^{\mathrm{c}} \\
0.5\end{array}$ & RIA & [103] \\
\hline FE1 & $2(455-505 ;$ site IV) & $\begin{array}{l}- \\
-\end{array}$ & $\begin{array}{l}1.8^{\mathrm{c}} \\
0.5\end{array}$ & RIA & [103] \\
\hline
\end{tabular}

Monoclonal antibodies against HA subtype $\mathrm{H} 1$

\begin{tabular}{l|l|l|c|} 
Y8-10C2 & $1(\mathrm{Sa})$ & - & $4.4 \cdot 10^{-2}$ \\
H17-L2 & $1(\mathrm{Ca})$ & - & 11.9 \\
H28-E23 & $1(\mathrm{Sb})$ & - & 1
\end{tabular}

Polyclonal antibodies against polypeptides ${ }^{\mathrm{d}}$
11
$1(105-139)$
\begin{tabular}{l|l}
$0.6^{\mathrm{a}}$ & $0.6^{\mathrm{a}}$ \\
\hline
\end{tabular}
RIA
[102] 
Table 2 (Contd.)

\begin{tabular}{c|c|c|c|c|c}
\hline 1 & 2 & 3 & 4 & 5 & 6 \\
\hline & & & & & \\
17 & $1(174-197)$ & $0.15^{\mathrm{a}}$ & $0.15^{\mathrm{a}}$ & & \\
23 & $1(201-227)$ & $0.25^{\mathrm{a}}$ & $0.25^{\mathrm{a}}$ & & \\
24 & $1(266-302)$ & $0.1^{\mathrm{a}}$ & $0.1^{\mathrm{a}}$ & & \\
25 & $2(331-359)$ & $1.8 \cdot 10^{-2^{\mathrm{a}}}$ & $1.8 \cdot 10^{-2^{\mathrm{a}}}$ & & \\
\hline
\end{tabular}

${ }^{\text {a }}$ As determined at $\mathrm{pH} 7.0$ and 5.0 for the HA ectodomain in trimeric and monomeric forms, respectively.

${ }^{\mathrm{b}}$ The lower value does not exceed the background.

${ }^{c}$ As determined for the HA precursor (HA0).

${ }^{\mathrm{d}}$ Against HA fragments (numbers of amino acid residues are shown in parentheses).

same region of the protein surface; the $\mathrm{C}$ site and the $\mathrm{Cb}$ site do not overlap. The latter fact could be explained by the difference in the glycosylation profiles of these sites: the surface area corresponding to most of the subtype $\mathrm{H} 1$ $\mathrm{Cb}$ site is $N$-glycosylated at Asn 81 in some subtype $\mathrm{H} 3$ strains (e.g. A/Hong Kong/1/68), whereas a fragment of the HA surface corresponding to the $\mathrm{C}$ site in subtype $\mathrm{H} 3$ is $N$-glycosylated at Asn271 in some subtype H1 strains (e.g. A/PR/8/34) [94]. Similarly, glycosylation of the Ans165 residue in HA of the A/Hong Kong/1/68 strain masks the Sa site $[94,96]$.

Antibodies against various regions of the HA molecule could be used not only for discrimination between monomers and trimers, but also to monitor HA conformational transitions. Several articles have been published on changes in HA antigenic properties induced by $\mathrm{pH}$ decrease [97-100]. It was found that acidification transforms the structure of epitopes in the globular domain and leads to exposure of HA molecule regions that are screened at $\mathrm{pH} 7.0$ (see section "Structure and functions of hemagglutinins" of this review). When exposed, these regions become available for binding corresponding antibodies [101]. Thus, lowering $\mathrm{pH}$ to 5.0 increases $\mathrm{MAb}$ affinity to the HA2 N-terminal fragment (a.a. 331-329) by two orders of magnitude [102]. Experiments with an array of anti-HA2 MAbs identified four epitopes whose availability increases several-fold as a result of the $\mathrm{pH}-$ dependent conformational transition (Table 2) [103].

As mentioned above, glycosylation might reduce accessibility of HA epitopes. Due to conformational flexibility [104] and structural variability [105], $N$-glycans can sterically block the HA surface within a $10-15 \AA$ radius from the glycosylation site. If the screened regions overlap with antigenic determinants, the probability of antigen recognition by the antibody considerably decreases. Thus, mutation Asp63Asn and resulting glycosylation of the Asn residue decrease the affinity of the $\mathrm{MAb}$ for HA of the Hong Kong influenza virus (H3N2) [106]. Another example of such screening is the earlier mentioned masking of $\mathrm{C}$ and $\mathrm{Ca} / \mathrm{Sb}$ epitopes in the $\mathrm{A} / \mathrm{PR} / 8 / 34$ and $\mathrm{A} /$ Hong Kong/1/68 virus strains, respec- tively. Targeted abolishment of glycosylation sites, on the contrary, results in epitope unmasking in globular and fibrillar HA fragments [107].

However, there are some exceptions [108]. It is known that particular antibodies can bind in the vicinity of glycosylated Asn residues [109] and, in many cases, $N$ glycans act as mediators of this binding [110, 111]. Generally, $N$-glycans by themselves do not exhibit high antigenic activity; however, certain antibodies have been described that interact exclusively with a glycosylated form of the avian influenza virus HA and, therefore, could be used as secondary antibodies in the HA determination by the ELISA (see section "Enzyme immunoassay") [112].

Table 2 shows antibodies that could be used for selective detection of various HA forms. The specificity of these antibodies was determined from their relative affinity to various HA conformations in the hemagglutination inhibition assay (see section "Hemagglutination test"), radioimmunoprecipitation (RIP), or radioimmunoassay (RIA).

The RIP method includes introduction of a radioactive label in the antigen molecule, precipitation of the antigen-antibody complex, and estimation of the amount of bound antibodies from the decrease in radioactivity of the unbound antigen [113]. Labeled HA is usually purified from a cell culture infected with the virus in the presence of L- $\left.{ }^{35} \mathrm{~S}\right]$-methionine [43, 97]. Solidsupport RIA is based on the competition between labeled and non-labeled antibodies for binding with an immobilized antigen [92, 114]. RIA in a solution involves formation of complexes between labeled HA molecules and antibodies, immobilization of these complexes on protein A-Sepharose, and determination of radioactivity of the bound HA fraction [115]. Labeled HA or antibodies for RIA are usually obtained by radioiodination at tyrosine residues in $\mathrm{Na}^{125}$ I solution using chloramine $\mathrm{T}$ [116].

Identification of HA in a specific conformation/state requires solving two major problems: choosing antibodies with required specificity, and selecting the optimal immunochemical test. Further, in this article we consider 
possible solutions to these problems with specific references to the single radial immunodiffusion (SRID), immunoelectrophoresis (IEP), and enzyme-linked immunosorbent assay (ELISA) methods.

Single radial immunodiffusion (SRID) of Mancini. Single radial immunodiffusion (SRID) was developed in 1965 for quantitative analysis of antigens in vaccines and estimation of their activity with corresponding antibodies [117]. The method is based on the diffusion of viral antigen (HA, in our case) in an agarose gel containing antibodies at a known concentration. The area of diffusion is directly proportional to the amount of HA in the analyzed sample and inversely proportional to the working antibody concentration. Virus preparation with known HA concentration is used as a standard. SRID is now commonly used for testing anti-influenza vaccines [118].

HA trimers at the virus surface tend to associate with each other and other viral proteins [119]. Formed associates of varying molecular masses diffuse in the gel at different velocities, which results in deviation from direct proportionality between the area of diffusion and antigen concentration. To ensure accurate quantification, the HA should be in its trimeric form, which can be achieved by treating viral particles with nonionic $[118,120]$ or zwitterionic [121] detergents.

It is preferable to use polyclonal serum in SRID, since it provides sharper edges of the HA diffusion zone than MAbs [41, 59, 61, 122-126]. This considerably limits application of SRID for studying HA ligands, since this requires the use of antibodies able to compete with ligands for the binding of a particular HA epitope.

As mentioned above, HA molecules undergo conformational transitions as $\mathrm{pH}$ decreases from 7.0 to 5.0. It was found that the low-pH HA form could not be evaluated by SRID (Fig. 1b), despite that fact that the used polyclonal antibodies recognize both conformations. This phenomenon could be explained by removal of the low$\mathrm{pH}$ from the SRID assay because of its selective adsorption on the nitrocellulose filter during gel blotting [127129]. The ability to distinguish selectively native HA conformation is an important advantage of the SRID method.

Immunoelectrophoresis. The immunoelectrophoresis (IEP) procedure is like SRID except that HA migrates in the agarose gel under applied voltage [130]. The parameter measured in IEP is the length of the precipitation zone, which is the length of the HA run in the gel (vs. diameter of precipitation zone in SRID). Similarly to SRID, the efficiency of HA assay by IEP depends on the protein state, i.e. extent of oligomerization and conformation of antigenic determinants.

Enzyme-linked immunosorbent assay (ELISA). Enzyme-linked immunosorbent assay (ELISA) is a universal method that can be used for quantitative analysis of $\mathrm{HA}$ and investigation of HA ligands. The method includes HA immobilization, its interaction with a labeled antibody or an inhibitor, and label visualization. The most commonly used procedure is so-called sandwich ELISA that is 2-5-fold more sensitive that the standard protocol that includes antigen immobilization directly on a solid support [131]. The sandwich method requires the presence of at least two epitopes on the antigen molecule surface. The influenza virion contains several hundreds of surface HA molecules. Sandwich ELISA can be performed with [132] or without secondary antibodies [126, 133]. The main advantage of the indirect method is that once-generated secondary antibodies can be used in many experiments with HA from the same viral strain [132].

Antibodies used in ELISA might recognize particular states of HA. Both polyclonal serum and MAbs generated by standard hybridoma technologies can be used in ELISA [134]. MAbs have been obtained to various HA molecule epitopes (see section "Variety of anti-HA antibodies") that can be used for assaying HA in its specific conformational states.

To determine total content of HA (all states included), it is essential to use a combination of MAbs that recognize native and denatured HA to ensure HA identification irrespective of its conformation [132].

The use of MAbs in virus typing has one characteristic distinction from other methods. It is known that influenza virus strains experience antigenic drift; this also concerns HA antigens. This results in periodical seasonal mutations at least every 2-8 years [135-138]. The relative conservatism of HA antigenic determinants within a subtype allows use of the same MAb in ELISA for several years only. Thus, antibodies against HA from the A/Hiroshima/52/05 (H3N2) strain recognize all H3N2 strains isolated between 2000 and 2008, but cannot be used for the identification of earlier strains of this virus [134].

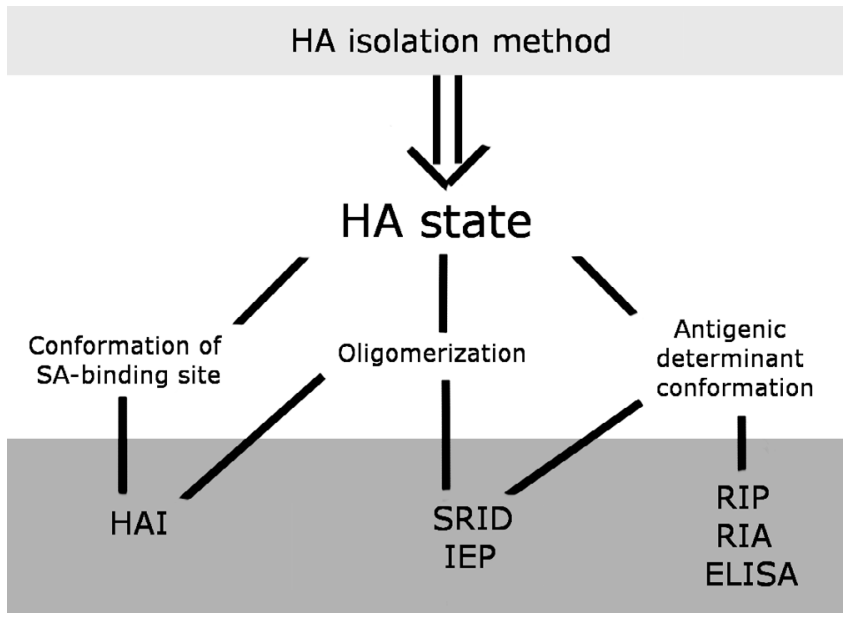

Fig. 4. Relationships between methods for HA isolation, HA states, and possibility of estimating HA state by hemagglutination- and antibody-based methods. 
As one of the two influenza virus surface antigens, $\mathrm{HA}$ is an essential component of anti-influenza vaccines $[139,140]$. It also plays an important role in influenza diagnostics [141] and serves as a target protein in the development of anti-influenza medications [14, 142144]. Functional and conformational changes that accompany HA processing and functioning during infection are mechanisms that ensure high polymorphism of the virus. This polymorphism complicates selective purification and identification of HA in its particular states, and therefore, significantly hinders development of inhibitors against these states. Inhibitors against specific HA states would not only directly suppress HA functioning, but also prevent some functionally important conformational transitions, which might considerably broaden the spectrum of potential antiviral agents. For example, Arbidol binds in the cavity between HAl and HA2 and stabilizes HA in a conformation that is typical for HA before membrane fusion (Fig. 1, a and b). It inhibits the $\mathrm{pH}$-dependent conformational transition of HA, thereby preventing correct virus internalization [8].

We summarize the capabilities and limitations of the hemagglutination-based tests and various immunological methods for HA assay in Fig. 4.

Existing procedures for studying influenza virus antigens allow selective determination of HA in virtually any state. Using hemagglutination-based tests, it is possible to investigate oligomeric HA and to design inhibitors against this form. The development of a broad array of MAbs against various $\mathrm{HA}$ epitopes made it possible to analyze not only HA oligomeric composition, but also more precise details of the HA structure. For example, ELISA can be used for distinguishing between HA trimers and monomers, between HA in the conformations typical for pH 5.0 and 7.0, and in some cases, between glycosylated and nonglycosylated HA forms, as well as for the development of inhibitors that would compete with MAbs for binding with specific epitopes. Since MAbs are not applicable in SRID and IEP, these two methods do not allow direct study of HA inhibition; however, they are widely used for determination of native HA prefusion conformations.

\section{Acknowledgments}

This study was supported by the Russian Science Foundation (project No. 15-13-00033).

\section{REFERENCES}

1. Smith, A. M., and McCullers, J. A. (2014) Secondary bacterial infections in influenza virus infection pathogenesis, Curr. Top. Microbiol. Immunol., 385, 327-356.

2. World Health Organization (2014) Influenza (Seasonal), Fact sheet No. 211.
3. Neumann, G., and Kawaoka, Y. (2015) Transmission of influenza A viruses, Virology, 479-480, 234-246.

4. Shi, Y., Wu, Y., Zhang, W., Qi, J., and Gao, G. F. (2014) Enabling the "host jump": structural determinants of receptor-binding specificity in influenza A viruses, Nat. Rev. Microbiol., 12, 822-831.

5. Shaw, M. L., and Palese, P. (2013) in Fields Virology, 6th Edn. (Knipe, D. M., and Howley, P., eds.) Lippincott Williams \& Wilkins, Wolters Kluwer Business, Philadelphia, pp. 1151-1185.

6. Leneva, I. A., Russell, R. J., Boriskin, Y. S., and Hay, A. J. (2009) Characteristics of Arbidol-resistant mutants of influenza virus: implications for the mechanism of antiinfluenza action of Arbidol, Antiviral Res., 81, 132-140.

7. Ivashchenko, A. V., Yamanushkin, P. M., Mit'kin, O. D., Leneva, I. A., and Fedyakina, I. T. (2011) Synthesis and antiviral activity of functionally substituted indole-3-acetic acids, Pharm. Chem. J., 45, 261-266.

8. Kadam, R. U., and Wilson, I. A. (2016) Structural basis of influenza virus fusion inhibition by the antiviral drug Arbidol, Proc. Natl. Acad. Sci. USA, 114, 206-214.

9. Ison, M. G. (2013) Clinical use of approved influenza antivirals: therapy and prophylaxis, Influenza Other Respir. Viruses, 7, 7-13.

10. Ison, M. G. (2011) Antivirals and resistance: influenza virus, Curr. Opin. Virol., 1, 563-573.

11. Jefferson, T., Jones, M., Doshi, P., Spencer, S. A., Onakpoya, I., and Heneghan, C. J. (2014) Oseltamivir for influenza in adults and children: systematic review of clinical study reports and summary of regulatory comments, BMJ, 348, g2545.

12. Heneghan, C. J., Onakpoya, I., Thompson, M., Spencer, S. A., Jones, M., and Jefferson, T. (2014) Zanamivir for influenza in adults and children: systematic review of clinical study reports and summary of regulatory comments, BMJ, 348, g2547.

13. World Health Organization (2010) WHO Guidelines for Pharmacological Management of Pandemic Influenza A(H1N1) 2009 and Other Influenza Viruses, WHO, Geneva.

14. Krol, E., Rychlowska, M., and Szewczyk, B. (2014) Antivirals - current trends in fighting influenza, Acta Biochim. Pol., 61, 495-504.

15. Zavyalova, E. G., and Kopylov, A. M. (2015) Aptamers to hemagglutinin: a novel tool for influenza virus recognition and neutralization, Curr. Pharm. Des., 22, 4835-4853.

16. Di Lella, S., Herrmann, A., and Mair, C. M. (2016) Modulation of the $\mathrm{pH}$ stability of influenza virus hemagglutinin: a host cell adaptation strategy, Biophys. J., 110, 22932301.

17. Tate, M. D., Job, E. R., Deng, Y. M., Gunalan, V., Maurer-Stroh, S., and Reading, P. C. (2014) Playing hide and seek: how glycosylation of the influenza virus hemagglutinin can modulate the immune response to infection, Viruses, 6, 1294-1316.

18. Blijleven, J. S., Boonstra, S., Onck, P. R., Van der Giessen, E., and Van Oijen, A. M. (2016) Mechanisms of influenza viral membrane fusion, Semin. Cell Dev. Biol., 60, 7888.

19. Velkov, T., Ong, C., Baker, M. A., Kim, H., Li, J., Nation, R. L., Huang, J. X., Cooper, M. A., and Rockman, S. (2013) The antigenic architecture of the hemagglutinin of influenza H5N1 viruses, Mol. Immunol., 56, 705-719. 
20. Suzuki, Y., and Nei, M. (2002). Origin and evolution of influenza virus hemagglutinin genes, Mol. Biol. Evol., 19, 501-509.

21. Gething, M. J., McCammon, K., and Sambrook, J. (1986) Expression of wild-type and mutant forms of influenza hemagglutinin: the role of folding in intracellular transport, Cell, 46, 939-950.

22. Yewdell, J. W., Yellen, A., and Bachi, T. (1988) Monoclonal antibodies localize events in the folding, assembly, and intracellular transport of the influenza virus hemagglutinin glycoprotein, Cell, 52, 843-852.

23. Russ, G., Bennink, J. R., Bachi, T., and Yewdell, J. W. (1991) Influenza virus hemagglutinin trimers and monomers maintain distinct biochemical modifications and intracellular distribution in brefeldin A-treated cells, Cell Regul., 2, 549-563.

24. Roberts, P. C., Garten, W., and Klenk, H. D. (1993) Role of conserved glycosylation sites in maturation and transport of influenza A virus hemagglutinin, J. Virol., 67, 3048-3060.

25. McCauley, J., Bye, J., Elder, K., Gething, M. J., Skehel, J. J., Smith, A., and Waterfield, M. D. (1979) Influenza virus haemagglutinin signal sequence, FEBS Lett., 108, 422-426.

26. Schmidt, M. F. G., and Lambrecht, B. (1985) On the structure of the acyl linkage and the function of fatty acyl chains in the influenza virus haemagglutinin and the glycoproteins of Semliki Forest virus, J. Gen. Virol., 66, 2635-2647.

27. Lazarowitz, S. G., Compans, R. W., and Choppin, P. W. (1973) Proteolytic cleavage of the hemagglutinin polypeptide of influenza virus. Function of the uncleaved polypeptide HA, Virology, 52, 199-212.

28. Klenk, H. D., Rott, R., Orlich, M., and Blodorn, J. (1975) Activation of influenza A viruses by trypsin treatment, Virology, 68, 426-439.

29. Stieneke-Grober, A., Vey, M., Angliker, H., Shaw, E., Thomas, G., Roberts, C., Klenk, H. D., and Garten, W. (1992) Influenza virus hemagglutinin with multibasic cleavage site is activated by furin, a subtilisin-like endoprotease, EMBO J., 11, 2407-2414.

30. Bertram, S., Glowacka, I., Steffen, I., Kuhl, A., and Pohlmann, S. (2010) Novel insights into proteolytic cleavage of influenza virus hemagglutinin, Rev. Med. Virol., 20, 298-310.

31. Waterfield, M. D., Espelie, K., Elder, K., and Skehel, J. J. (1979) Structure of the haemagglutinin of influenza virus, Br. Med. Bull., 35, 57-63.

32. Bullough, P. A., Hughson, F. M., Skehel, J. J., and Wiley, D. C. (1994) Structure of influenza haemagglutinin at the $\mathrm{pH}$ of membrane fusion, Nature, 371, 37-43.

33. Weis, W. I., Brunger, A. T., Skehel, J. J., and Wiley, D. C. (1990) Refinement of the influenza virus hemagglutinin by simulated annealing, J. Mol. Biol., 212, 737-761.

34. Chen, J., Lee, K. H., Steinhauer, D. A., Stevens, D. J., Skehel, J. J., and Wiley, D. C. (1998) Structure of the hemagglutinin precursor cleavage site, a determinant of influenza pathogenicity and the origin of the labile conformation, Cell, 95, 409-417.

35. Wiley, D. C., Wilson, I. A., and Skehel, J. J. (1981) Structural identification of the antibody-binding sites of Hong Kong influenza haemagglutinin and their involvement in antigenic variation, Nature, 289, 373-378.

36. Weis, W., Brown, J. H., Cusack, S., Paulson, J. C., Skehel, J. J., and Wiley, D. C. (1988) Structure of the influenza virus haemagglutinin complexed with its receptor, sialic acid, Nature, 333, 426-431.

37. Wang, W., DeFeo, C. J., Alvarado-Facundo, E., Vassell., R., and Weiss, C. D. (2015) Intermonomer interactions in hemagglutinin subunits HA1 and HA2 affecting hemagglutinin stability and influenza virus infectivity, J. Virol., 89, 10602-10611.

38. Doms, R. W., and Helenius, A. (1986) The quaternary structure of the influenza virus hemagglutinin after acid treatment, J. Virol., 60, 833-839.

39. Kemble, G. W., Henis, Y. I., and White, J. M. (1993) GPIand transmembrane-anchored influenza hemagglutinin differ in structure and receptor binding activity, J. Cell Biol., 122, 1253-1265.

40. Xu, S., Zhou, J., Liu, Q., Liu, K., Xue, C., Li, X., Zheng, J., Luo, D., and Cao, Y. (2014) Evidences for the existence of intermolecular disulfide-bonded oligomers in the H3 hemagglutinins expressed in insect cells, Virus Genes, 48, 304-311.

41. Khurana, S., Larkin, C., Verma, S., Joshi, M. B., Fontana, J., Steven, A. C., King, L. R., Manischewitz, J., McCormick, W., Gupta, R. K., and Golding, H. (2011) Recombinant HA1 produced in $E$. coli forms functional oligomers and generates strain-specific SRID potency antibodies for pandemic influenza vaccines, Vaccine, 29, 56575665.

42. Khurana, S., Verma, S., Verma, N., Crevar, C. J., Carter, D. M., Manischewitz, J., King, L. R., Ross, T. M., and Golding, H. (2011) Bacterial HAl vaccine against pandemic H5N1 influenza virus: evidence of oligomerization, hemagglutination, and cross-protective immunity in ferrets, J. Virol., 85, 1246-1256.

43. Copeland, C. S., Doms, R. W., Bolzau, E. M., Webster, R. G., and Helenius, A. (1986) Assembly of influenza hemagglutinin trimers and its role in intracellular transport, J. Cell Biol., 703, 1179-1191.

44. Carr, C. M., and Kim, P. S. (1993) A spring-loaded mechanism for the conformational change of influenza hemagglutinin, Cell, 73, 823-832.

45. Chen, J., Skehel, J. J., and Wiley, D. C. (1999) N- and Cterminal residues combine in the fusion-pH influenza hemagglutinin $\mathrm{HA}_{2}$ subunit to form an $\mathrm{N}$ cap that terminates the triple-stranded coiled coil, Proc. Natl. Acad. Sci. USA, 96, 8967-8972.

46. Harrison, S. C. (2008) Viral membrane fusion, Nat. Struct. Mol. Biol., 15, 690-698.

47. Russell, C. J. (2014) Acid-induced membrane fusion by the hemagglutinin protein and its role in influenza virus biology, Curr. Top Microbiol. Immunol., 385, 93-116.

48. Ruigrok, R. W. H., Martin, S. R., Wharton, S. A., Skehel, J. J., Bayley, P. M., and Wiley, D. C. (1986) Conformational changes in the hemagglutinin of influenza virus which accompany heat-induced fusion of virus with liposomes, Virology, 755, 484-497.

49. Kornfeld, R., and Kornfeld, S. (1985) Assembly of asparagine-linked oligosaccharides, Annu. Rev. Biochem., 54, 631-664.

50. Nobusawa, E., Aoyama, T., Kato, H., Suzuki, Y., Tateno, Y., and Nakajima, K. (1991) Comparison of complete amino acid sequences and receptor-binding properties among 13 serotypes of hemagglutinins of influenza viruses, Virology, 182, 475-485. 
51. Compans, R. W., Klenk, H. D., Caliguiri, L. A., and Choppin, P. W. (1970) Influenza virus proteins: I. Analysis of polypeptides of the virion and identification of spike glycoproteins, Virology, 42, 880-889.

52. Skehel, J. J., and Schild, G. C. (1971) The polypeptide composition of influenza A viruses, Virology, 44, 396-408.

53. Stanley, P., Crook, N. E., Streader, L. G., and Davidson, B. E. (1973) The polypeptides of influenza virus. 8. Largescale purification of the hemagglutinin, Virology, 56, 640645.

54. Bachmayer, H. (1975) Selective solubilization of hemagglutinin and neuraminidase from influenza viruses, Intervirology, 5, 260-272.

55. Collins, J. K., and Knight, C. A. (1978) Purification of the influenza hemagglutinin glycoprotein and characterization of its carbohydrate components, J. Virol., 26, 457-467.

56. Saczynska, V. (2014) Influenza virus hemagglutinin as a vaccine antigen produced in bacteria, Acta Biochim. Pol., 61, 561-572.

57. Baneyx, F., and Mujacic, M. (2004) Recombinant protein folding and misfolding in Escherichia coli, Nat. Biotechnol., 22, 1399-1408.

58. Farahmand, B., Khodabandeh, M., Mahboudi, F., Fotouhi, F., Saleh, M., Barkhordari, F., Tabatabaian, M., Nasab, F. P., and Kheiri, M. T. (2012) Influenza virus hemagglutinin: a model for protein N-glycosylation in recombinant Escherichia coli, Intervirology, 55, 219-224.

59. Wang, K., Holtz, K. M., Anderson, K., Chubet, R., Mahmoud, W., and Cox, M. M. (2006) Expression and purification of an influenza hemagglutinin - one step closer to a recombinant protein-based influenza vaccine, Vaccine, 24, 2176-2185.

60. Cox, M. M., and Anderson, K. D. (2007) Production of a novel influenza vaccine using insect cells: protection against drifted strains, Influenza Other Respir. Viruses, 1, $35-40$.

61. Feshchenko, E., Rhodes, D. G., Felberbaum, R., McPherson, C., Rininger, J. A., Post, P., and Cox, M. M. (2012) Pandemic influenza vaccine: characterization of A/California/07/2009 (H1N1) recombinant hemagglutinin protein and insights into $\mathrm{H} 1 \mathrm{~N} 1$ antigen stability, $B M C$ Biotechnol., 12, 77.

62. Altmann, F., Kornfeld, G., Dalik, T., Staudacher, E., and Glossl, J. (1993) Processing of asparagine-linked oligosaccharides in insect cells. N-acetylglucosaminyltransferase I and II activities in cultured lepidopteran cells, Glycobiology, 3, 619-625.

63. Altmann, F., Schwihla, H., Staudacher, E., Glossl, J., and Marz, L. (1995) Insect cells contain an unusual, membrane-bound $\beta$-N-acetylglucosaminidase probably involved in the processing of protein N-glycans, J. Biol. Chem., 270, 17344-17349.

64. Wagner, R., Geyer, H., Geyer, R., and Klenk, H. D. (1996) $\mathrm{N}$-Acetyl- $\beta$-glucosaminidase accounts for differences in glycosylation of influenza virus hemagglutinin expressed in insect cells from a baculovirus vector, J. Virol., 70, 41034109.

65. Hooker, A. D., Green, N. H., Baines, A. J., Bull, A. T., Jenkins, N., Strange, P. G., and James, D. C. (1999) Constraints on the transport and glycosylation of recombinant IFN- $\gamma$ in Chinese hamster ovary and insect cells, Biotechnol. Bioeng., 63, 559-572.
66. Seo, N. S., Hollister, J. R., and Jarvis, D. L. (2001) Mammalian glycosyltransferase expression allows sialoglycoprotein production by baculovirus-infected insect cells, Protein Expr. Purif., 22, 234-241.

67. Jarvis, D. L., Howe, D., and Aumiller, J. J. (2001) Novel baculovirus expression vectors that provide sialylation of recombinant glycoproteins in lepidopteran insect cells, $J$. Virol., 75, 6223-6227.

68. Hill, D. R., Aumiller, J. J., Shi, X., and Jarvis, D. L. (2006) Isolation and analysis of a baculovirus vector that supports recombinant glycoprotein sialylation by SfSWT-1 cells cultured in serum-free medium, Biotechnol. Bioeng., 95, 37-47.

69. Aumiller, J. J., Hollister, J. R., and Jarvis, D. L. (2003) A transgenic insect cell line engineered to produce CMP-sialic acid and sialylated glycoproteins, Glycobiology, 13, 497507.

70. Aumiller, J. J., Mabashi-Asazuma, H., Hillar, A., Shi, X., and Jarvis, D. L. (2012) A new glycoengineered insect cell line with an inducibly mammalianized protein N-glycosylation pathway, Glycobiology, 22, 417-428.

71. Toth, A. M., Kuo, C. W., Khoo, K. H., and Jarvis, D. L. (2014) A new insect cell glycoengineering approach provides baculovirus-inducible glycogene expression and increases human-type glycosylation efficiency, $J$. Biotechnol., 182-183, 19-29.

72. Li, Z. N., and Steinhauer, D. A. (2007) Expression and purification of viral glycoproteins using recombinant vaccinia viruses for functional and structural studies, Methods Mol. Biol., 379, 85-95.

73. Neumann, G., Watanabe, T., and Kawaoka, Y. (2000) Plasmid-driven formation of influenza virus-like particles, J. Virol., 74, 547-551.

74. Schmeisser, F., Adamo, J. E., Blumberg, B., Friedman, R., Muller, J., Soto, J., and Weir, J. P. (2012) Production and characterization of mammalian virus-like particles from modified vaccinia virus Ankara vectors expressing influenza H5N1 hemagglutinin and neuraminidase, Vaccine, 30, 3413-3422.

75. Wu, C. Y., Yeh, Y. C., Yang, Y. C., Chou, C., Liu, M. T., and $\mathrm{Wu}$, H. S. (2010) Mammalian expression of virus-like particles for advanced mimicry of authentic influenza virus, PLoS One, 5, e9784.

76. Salk, J. E. (1944) A simplified procedure for titrating hemagglutinating capacity of influenza virus and the corresponding antibody, J. Immunol., 49, 87-98.

77. Mammen, M., Dahmann, G., and Whitesides, G. M. (1995) Effective inhibitors of hemagglutination by influenza virus synthesized from polymers having active ester groups. Insight into mechanism of inhibition, J. Med. Chem., 38, 4179-4190.

78. Spaltenstein, A., and Whitesides, G. M. (1991) Polyacrylamides bearing pendant $\alpha$-sialoside groups strongly inhibit agglutination of erythrocytes by influenza virus, J. Am. Chem. Soc., 113, 686-687.

79. Sigal, G. B., Mammen, M., Dahmann, G., and Whitesides, G. M. (1996) Polyacrylamides bearing pendant R-sialoside groups strongly inhibit agglutination of erythrocytes by influenza virus: the strong inhibition reflects enhanced binding through cooperative polyvalent interactions, J. Am. Chem. Soc., 118, 3789-3800.

80. Choi, S.-K., Mammen, M., and Whitesides, G. M. (1997) Generation and in situ evaluation of libraries of poly(acrylic 
acid) presenting sialosides as side chains as polyvalent inhibitors of influenza-mediated hemagglutination, J. Am. Chem. Soc., 119, 4103-4111.

81. Knowles, J. R., and Weinhold, E. (1992) Design and evaluation of a tightly binding fluorescent ligand for influenza A hemagglutinin, J. Am. Chem. Soc., 114, 9270-9275.

82. Toogood, P. L., Galliker, P. K., Glick, G. D., and Knowles, J. R. (1991) Monovalent sialosides that bind tightly to influenza A virus, J. Med. Chem., 34, 3140-3143.

83. Kingery-Wood, J. E., Williams, K. W., Sigal, G. B., and Whitesides, G. M. (1992) The agglutination of erythrocytes by influenza virus is strongly inhibited by liposomes incorporating an analog of sialyl gangliosides, J. Am. Chem. Soc., 114, 7303-7305.

84. Spevak, W., Nagy, J. O., Charych, D. H., Schaefer, M. E., Gilbert, J. H., and Bednarski, M. D. (1993) Polymerized liposomes containing $\mathrm{C}$-glycosides of sialic acid: potent inhibitors of influenza virus in vitro infectivity, J. Am. Chem. Soc., 115, 1146-1147.

85. Pritchett, T. J., and Paulson, J. C. (1989) Basis for the potent inhibition of influenza virus infection by equine and guinea pig $\alpha_{2}$-macroglobulin, J. Biol. Chem., 264, 98509858.

86. Khurana, S., Verma, S., Verma, N., Crevar, C. J., Carter, D. M., Manischewitz, J., King, L. R., Ross, T. M., and Golding, H. (2010) Properly folded bacterially expressed H1N1 hemagglutinin globular head and ectodomain vaccines protect ferrets against $\mathrm{H} 1 \mathrm{~N} 1$ pandemic influenza virus, PLoS One, 5, e11548.

87. Bottcher-Friebertshauser, E., Garten, W., Matrosovich, M., and Klenk, H. D. (2014) The hemagglutinin: a determinant of pathogenicity, Curr. Top. Microbiol. Immunol., 385, 3-30.

88. Xiong, X., McCauley, J. W., and Steinhauer, D. A. (2014) Receptor binding properties of the influenza virus hemagglutinin as a determinant of host range, Curr. Top. Microbiol. Immunol., 385, 63-91.

89. Webster, R. G., and Laver, W. G. (1980) Determination of the number of nonoverlapping antigenic areas on Hong Kong (H3N2) influenza virus hemagglutinin with the selection of variants with potential epidemiological significance, Virology, 104, 139-148.

90. Copeland, C. S., Zimmer, K. P., Wagner, K. R., Healey, G. A., Mellman, I., and Helenius, A. (1988) Folding, trimerization, and transport are sequential events in the biogenesis of influenza virus hemagglutinin, Cell, 53, 197-209.

91. Nestorowicz, A., Laver, G., and Jackson, D. C. (1985) Antigenic determinants of influenza virus haemagglutinin. $\mathrm{X}$. A comparison of the physical and antigenic properties of monomeric and trimeric forms, J. Gen. Virol., 66, 16871695.

92. Nestorowicz, A., White, D. O., and Jackson, D. C. (1985) Conformational changes in influenza virus haemagglutinin and its monomer detected by monoclonal antibodies, Vaccine, 3S, 175-181.

93. Gerhard, W., Yewdell, J., Frankel, M. E., and Webster, R. (1981) Antigenic structure of influenza virus haemagglutinin defined by hybridoma antibodies, Nature, 290, 713716.

94. Caton, A. J., and Brownlee, G. G. (1982) The antigenic structure of the influenza virus A/PR/8/34 hemagglutinin (H1 subtype), Cell, 31, 417-427.
95. Magadan, J. G., Khurana, S., Das, S. R., Frank, G. M., Stevens, J., Golding, H., Bennink, J. R., and Yewdell, J. W. (2013) Influenza A virus hemagglutinin trimerization completes monomer folding and antigenicity, J. Virol., 87, 9742-9753.

96. Wilson, I. A., Skehel, J. J., and Wiley, D. C. (1981) Structure of the haemagglutinin membrane glycoprotein of influenza virus at $3 \AA$ A resolution, Nature, 89, 366-373.

97. Webster, R. G., Brown, L. E., and Jackson, D. C. (1983) Changes in the antigenicity of the hemagglutinin molecule of H3 influenza virus at acidic pH, Virology, 126, 587-599.

98. Jackson, D. C., Murray, J. M., Anders, E. M., White, D. O., Webster, R. G., and Brown, L. E. (1983) Expression of a unique antigenic determinant of influenza virus hemagglutinin at $\mathrm{pH} \mathrm{5}$, in The Origin of Pandemic Influenza Viruses (Laver, W. G., ed.) Elsevier Science, New York, pp. 29-38.

99. Daniels, R. S., Douglas, A. E., Skehel, J. J., and Wiley, D. C. (1983) Analyses of the antigenicity of influenza hemagglutinin at the $\mathrm{pH}$ optimum for virus-mediated membrane fusion, J. Gen. Virol., 64, 1657-1662.

100. Yewdell, J. W., Gerhard, W., and Bachi, T. (1983) Monoclonal antihemagglutinin antibodies detect irreversible antigenic alterations that coincide with the acid activation of influenza virus A/PR/8/34-mediated hemolysis, J. Virol., 48, 239-248.

101. Jackson, D. C., and Nestorowicz, A. (1985) Antigenic determinants of influenza virus hemagglutinin. XI. Conformational changes detected by monoclonal antibodies, Virology, 145, 72-83.

102. White, J. M., and Wilson, I. A. (1987) Anti-peptide antibodies detect steps in a protein conformational change: low-pH activation of the influenza virus hemagglutinin, $J$. Cell Biol., 105, 2887-2896.

103. Vareckova, E., Mucha, V., Wharton, S. A., and Kostolansky, F. (2003) Inhibition of fusion activity of influenza A haemagglutinin mediated by HA2-specific monoclonal antibodies, Arch. Virol., 148, 469-486.

104. Varki, A., Cummings, R. D., Esko, J. D., Freeze, H. H., Stanley, P., Bertozzi, C. R., Hart, G. W., and Etzler, M. E. (2009) Essentials of Glycobiology, 2nd Edn., Cold Spring Harbor Laboratory Press, Cold Spring Harbor, NY.

105. Keil, W., Geyer, R., Dabrowski, J., Dabrowski, U., Niemann, H., Stirm, S., and Klenk, H. D. (1985) Carbohydrates of influenza virus. Structural elucidation of the individual glycans of the FPV hemagglutinin by twodimensional ${ }^{1} \mathrm{H}$ NMR and methylation analysis, EMBO J., 4, 2711-2720.

106. Skehel, J. J., Stevens, D. J., Daniels, R. S., Douglas, A. R., Knossow, M., Wilson, I. A., and Wiley, D. C. (1984) A carbohydrate side chain on hemagglutinins of Hong Kong influenza viruses inhibits recognition by a monoclonal antibody, Proc. Natl. Acad. Sci. USA, 81, 17791783.

107. Liu, W. C., Jan, J. T., Huang, Y. J., Chen, T. H., and Wu, S. C. (2016) Unmasking stem-specific neutralizing epitopes by abolishing N-linked glycosylation sites of influenza virus hemagglutinin proteins for vaccine design, $J$. Virol., 90, 8496-508.

108. Pentiah, K., Lees, W. D., Moss, D. S., and Shepherd, A. J. (2015) N-linked glycans on influenza A H3N2 hemagglu- 
tinin constrain binding of host antibodies, but shielding is limited, Glycobiology, 25, 124-132.

109. Corti, D., Voss, J., Gamblin, S. J., Codoni, G., Macagno, A., Jarrossay, D., Vachieri, S. G., Pinna, D., Minola, A., Vanzetta, F., Silacci, C., Fernandez-Rodriguez, B. M., Agatic, G., Bianchi, S., Giacchetto-Sasselli, I., Calder, L., Sallusto, F., Collins, P. J., Haire, L. F., Temperton, N., Langedijk, J. P. M., Skehel, J. J., and Lanzavecchia, A. (2011) A neutralizing antibody selected from plasma cells that binds to group 1 and group 2 influenza A hemagglutinins, Science, 333, 850-856.

110. Barbey-Martin, C., Gigant, B., Bizebard, T., Calder, L. J., Wharton, S. A., Skehel, J. J., and Knossow, M. (2002) An antibody that prevents the hemagglutinin low $\mathrm{pH}$ fusogenic transition, Virology, 294, 70-74.

111. Iba, Y., Fujii, Y., Ohshima, N., Sumida, T., KubotaKoketsu, R., Ikeda, M., Wakiyama, M., Shirouzu, M., Okada, J., Okuno, Y., Kurosawa, Y., and Yokoyama, S. (2014) Conserved neutralizing epitope at globular head of hemagglutinin in $\mathrm{H} 3 \mathrm{~N} 2$ influenza viruses, J. Virol., 88, 7130-7144.

112. Legastelois, I., Chevalier, M., Bernard, M. C., de Montfort, A., Fouque, M., Pilloud, A., Serraille, C., Devard, N., Engel, O., Sodoyer, R., and Moste, C. (2011) Avian glycan-specific IgM monoclonal antibodies for the detection and quantitation of type A and B haemagglutinins in egg-derived influenza vaccines, J. Virol. Methods, 178, 129-136.

113. Fernie, B. F., and Gerin, J. L. (1982) Immunochemical identification of viral and nonviral proteins of the respiratory syncytial virus virion, Infect. Immun., 37, 243249.

114. Jackson, D. C., Murray, J. M., White, D. O., and Gerhard, W. U. (1982) Enumeration of antigenic sites of influenza virus hemagglutinin, Infect. Immun., 37, 912-918.

115. Jackson, D. C., Brown, L. E., White, D. O., Dopheide, T. A., and Ward, C. W. (1979) Antigenic determinants of influenza virus hemagglutinin. IV. Immunogenicity of fragments isolated from the hemagglutinin of A/Memphis/72, J. Immunol., 123, 2610-2617.

116. Jackson, D. C. (1980) Some effects of chloramine T induced radioiodination on the physico-chemical properties of oligomeric proteins, J. Immunol. Methods, 34, 253260.

117. Mancini C. A., and Herenan, J. F. (1965) Immunochemical quantitation of immunoglobulins by SRID, Immunol. Chem., 2, 235-254.

118. Williams, M. S., Mayner, R. E., Daniel, N. J., Phelan, M. A., Rastogi, S. C., Bozeman, F. M., and Ennis, F. A. (1980) New developments in the measurement of the hemagglutinin content of influenza virus vaccines by single-radial-immunodiffusion, J. Biol. Stand., 8, 289296.

119. Tay, T., Agius, C., Hamilton, R., Bodle, J., and Rockman, S. (2015) Investigation into alternative testing methodologies for characterization of influenza virus vaccine, Hum. Vaccines Immunother., 11, 1673-1684.

120. Wood, J. M., Seagroatt, V., Schild, G. C., Mayner, R. E., and Ennis, F. A. (1981) International collaborative study of single-radial-diffusion and immunoelectrophoresis techniques for the assay of haemagglutinin antigen of influenza virus, J. Biol. Stand., 9, 317-330.
121. Williams, M. S. (1993) Single-radial-immunodiffusion as an in vitro potency assay for human inactivated viral vaccines, Vet. Microbiol., 37, 253-262.

122. Schmeisser, F., Vodeiko, G. M., Lugovtsev, V. Y., Stout, R. R., and Weir, J. P. (2010) An alternative method for preparation of pandemic influenza strain-specific antibody for vaccine potency determination, Vaccine, 28, 2442-2449.

123. Hickey, J. M., Holtz, K. M., Manikwar, P., Joshi, S. B., McPherson, C. E., Buckland, B., Srivastava, I. K., Middaugh, C. R., and Volkin, D. B. (2014) Mechanism of a decrease in potency for the recombinant influenza A virus hemagglutinin $\mathrm{H} 3$ antigen during storage, J. Pharm. Sci., 103, 821-827.

124. Xu, K., Shao, M., Liu, S., Cai, F., Gao, Q., Li, C., and Wang, J. (2014) Rapid preparation of antiserum against influenza virus (H7N9) hemagglutinin for single radial immunodiffusion assay, Chin. J. Microbiol. Immunol., 24, 146-148.

125. Brand, G. M., and Skehel, J. J. (1972) Crystalline antigen from the influenza virus envelope, Nat. New Biol., 238, 145-147.

126. Van de Donk, H. J., De Jong, J. C., Van Olderen, M. F., and Osterhaus, A. D. (1984) Monoclonal antibodies for the control of influenza virus vaccines, Dev. Biol. Stand., 57, 251-255.

127. Wen, Y., Palladino, G., Xie, Y., Ferrari, A., Ma, X., Han, L., Dormitzer, P. R., and Settembre, E. C. (2016) Trypsin pre-treatment corrects SRID over-estimation of immunologically active, pre-fusion HA caused by mixed immunoprecipitin rings, Vaccine, 34, 3388-3395.

128. Wen, Y., Han, L., Palladino, G., Ferrari, A., Xie, Y., Carfi, A., Dormitzer, P. R., and Settembre, E. C. (2015) Conformationally selective biophysical assay for influenza vaccine potency determination, Vaccine, 33, 5342-5349.

129. Quan, F. S., Li, Z. N., Kim, M. C., Yang, D., Compans, R. W., Steinhauer, D. A., and Kang, S. M. (2011) Immunogenicity of low-pH treated whole viral influenza vaccine, Virology, 417, 196-202.

130. Mayner, R. E., Blackburn, R. J., and Barry, E. W. (1977) Quantitation of influenza vaccine haemagglutinin by immunoelectrophoresis, Dev. Biol. Stand., 39, 169-178.

131. Margulies, D. H. (2000) Enzyme-linked immunosorbent assays, in Current Protocols in Immunology (Coligan, J. E., Kruisbeek, A. M., Margulies, D. H., Shevach, E. M., and Strober, W., eds.) John Wiley \& Sons, Inc., Newcastle, UK, pp. 2.1.9-2.1.13.

132. He, Q., Velumani, S., Du, Q., Lim, C. W., Ng, F. K., Donis, R., and Kwang, J. (2007) Detection of H5 avian influenza viruses by antigen-capture enzyme-linked immunosorbent assay using $\mathrm{H} 5$-specific monoclonal antibody, Clin. Vaccine Immunol., 14, 617-623.

133. Bodle, J., Verity, E. E., Ong, C., Vandenberg, K., Shaw, R., Barr, I. G., and Rockman, S. (2012) Development of an enzyme-linked immunoassay for the quantitation of influenza haemagglutinin: an alternative method to single radial immunodiffusion, Influenza Other Resp. Viruses, 7, 191-200.

134. Yokoyama, W. M. (2000) Production of monoclonal antibody, in Current Protocols in Immunology (Coligan, J. E., Kruisbeek, A. M., Margulies, D. H., Shevach, E. M., and Strober, W., eds.) John Wiley \& Sons, Inc., Newcastle, UK, pp. 2.5.1-2.5.17. 
135. Smith, D. J., Lapedes, A. S., De Jong, J. C., Bestebroer, T. M., Rimmelzwaan, G. F., and Osterhaus, A. D. (2004) Mapping the antigenic and genetic evolution of influenza virus, Science, 305, 371-376.

136. Plotkin, J. B., Dushoff, J., and Levin, S. A. (2002) Hemagglutinin sequence clusters and the antigenic evolution of influenza A virus, Proc. Natl. Acad. Sci. USA, 99, 6263-6268.

137. Koelle, K., Cobey, S., Grenfell, B., and Pascual, M. (2006) Epochal evolution shapes the phylodynamics of interpandemic influenza A (H3N2) in humans, Science, 314, 1898-1903.

138. Carrat, F., and Flahault, A. (2007) Influenza vaccine: the challenge of antigenic drift, Vaccine, 25, 6852-6862.

139. Krammer, F., and Palese, P. (2015) Advances in the development of influenza virus vaccines, Nat. Rev. Drug Discov., 14, 167-182.
140. Barberis, I., Myles, P., Ault, S. K., Bragazzi, N. L., and Martini, M. (2016) History and evolution of influenza control through vaccination: from the first monovalent vaccine to universal vaccines, J. Prev. Med. Hyg., 57, E115-E120.

141. Peaper, D. R., and Landry, M. L. (2014) Rapid diagnosis of influenza: state of the art, Clin. Lab. Med., 34, 365385 .

142. Boltz, D. A., Aldridge, J. R., Jr., Webster, R. G., and Govorkova, E. A. (2010) Drugs in development for influenza, Drugs, 70, 1349-1362.

143. Yang, J., Li, M., Shen, X., and Liu, S. (2013) Influenza A virus entry inhibitors targeting the hemagglutinin, Viruses, 5, 352-373.

144. Zeng, L. Y., Yang, J., and Liu, S. (2017) Investigational hemagglutinin-targeted influenza virus inhibitors, Expert Opin. Investig. Drugs, 26, 63-73. 